\title{
Relationship Between Mother's Knowledge Levels About Food Assisted With Association With Timeliness Of Giving
}

\author{
Ayu Andhira ${ }^{1}$, Safruddin ${ }^{2 *}$, Tenriwati ${ }^{3}$, Haerati $^{4}$ \\ ${ }^{I}$ Nursing Student, Stikes Panrita Husada Bulukumba, Indonesia \\ ${ }^{2,3,4}$ Department of Nursing Stikes Panrita Husada Bulukumba, Indonesia
}

Corresponding author: Safruddin

Email: safaryahya1@gmail.com

\begin{abstract}
Complementary feeding should be given after the baby is 6 months old because it can provide great benefits to the baby (Kodrat, 2010). Factors that play an important role in preventing improper complementary feeding are the mother's knowledge and work factors. Mother's behavior in this case plays an important role in preventing improper complementary feeding so that it will reduce the risk of the baby experiencing digestive disorders and can have a stronger immune system. Some mothers do not provide complimentary foods on time. To find out the relationship between the level of knowledge of mothers about complementary foods with the timeliness of complementary feeding in the working area of Puskesmas Caile. This type of research is a quantitative study using a non-experimental design using a cross-sectional approach. The sample of this study was 49 respondents who were taken by consecutive sampling method. The data analysis in this study used the chi-square test statistical test. Based on the results of univariate analysis, it is known that the knowledge of mothers about complementary feeding is at the most sufficient and good categories as many as 44 people $(67.7 \%)$. And the timeliness of giving complementary foods was in the most precise category as many as 38 people $(58.5 \%)$. The results of the analysis using the chi-square test obtained a significant value of $0.001(\mathrm{p}$ $<0.05)$. There is a relationship between the level of knowledge of mothers about complementary foods with breastfeeding and the timeliness of complementary feeding. And it is suggested that the hospital institution is expected to consider its implementation as nursing care regarding the relationship between the level of knowledge of mothers about complementary foods with breastfeeding and the timeliness of complementary feeding.
\end{abstract}

Keywords: Knowledge Of Mothers, Complementary Foods. 


\section{PENDAHULUAN}

Makanan pendamping ASI (MP-ASI) harus diberikan pada umur yang tepat sesuai kebutuhan dan daya cerna bayi. Adanya kebiasaan masyarakat untuk memberikan nasi, bubur dan pisang pada usia terlalu dini ada bahayanya, karena saluran pencernaan pada bayi belum sempurna. Makanan pendamping ASI adalah makanan yang diberikan pada bayi atau anak disamping ASI mulai usia 6 bulan secara bertahap. Bayi mengalami pertumbuhan pesat, sehingga disamping ASI bayi memerlukan makanan pendamping yang baik dan bergizi seimbang untuk pertumbuhanya, (Sari and Wigunantiningsih, 2010). World Health Organization (WHO) 2015 menyatakan bahwa hanya 63\% bayi di dunia yang mendapatkan ASI eksklusif sedangkan 37\% bayi lainnya ternyata telah mendapatkan MPASI saat usianya < dari 6 bulan. Hal ini menggambarkan bahwa praktek pemberian MP-ASI dini diberbagai negara masih cukup tinggi. World Health Organization (WHO) juga mempersentasekan nahwa sekitar $32 \%$ anak usia balita di negara-negara berkembang menderita stunting dan $10 \%$ wasting disebabkan oleh MP-ASI yang tidak optimal.

Data demografi kesehatan provinsi Sulawesi Selatan tentang cakupan pemberian makanan pendamping ASI (MP-ASI) di tiga tahun terakhir yakni pada tahun 2017 cakupan pemberian makanan pendamping ASI (MP-ASI) sebesar 80,46\%, dan pada tahun 2018 mengalami penurunan renstra ke 73,56\%. Sementara pada tahun 2019 cakupan pemberian makanan pendamping ASI (MP-ASI) kembali meningkat dan mencapai angka 81,33\%. Pemberian makanan pendamping ASI pada 13.820 balita yang tersebar di 24 Kabupaten/kota, terdapat 5 (lima) Kabupaten/kota dengan capaian proporsi tertinggi cakupan pemberian MP-ASI yakni Kabupaten Sinjai, Bantaeng, Takalar, Sindrap dan Maros dengan persentase rata-rata mencapai $44 \%$, data ini lebih tinggi dibandingkan target renstra provinsi secara nasional yakni 34,5\%.

Hal ini menggambarkan bahwa kecenderungan masyarakat Sulawesi Selatan mengetahui dan memahami pentingnya pemberian makanan pendampin ASI untuk kesehatan dan tumbuh kembang bayi (Dinkes Sul-Sel, 2019). Survei awal yang dilakukan peneliti di Puskesmas Caile Kab. Bulukumba pada tahun 2017 jumlah ibu yang memberikan makanan pendamping ASI sebanyak 221 (28\%), pada tahun 2018 yaitu sebanyak 297 orang (38\%), pada tahun 2019 sebanyak 263 (34\%) dan pada tahun 2019 sebanyak 34 (4\%) yang mengalami penurunan dari tahun-tahun sebelumnya, sedangkan pada tahun 2020 pada bulan januari yaitu berkisar 33 orang $(13,7 \%)$. Tujuan dalam penelitian ini adalah terdapat hubungan antara tingkat pengetahuan ibu 
tentang makanan pendamping ASI dengan ketepatan waktu pemberian makanan pendamping ASI di Wilayah Kerja Puskesmas Caile Kabupaten Bulukumba.

\section{BAHAN DAN METODE}

\section{Desain Penelitian}

Desain penelitian merupakan rencana penelitian yang disusun sedemikian rupa sehingga peneliti dapat memperoleh jawaban yang sesuai terhadap pertanyaan penelitian. Jenis penelitian ini adalah jenis penelitian kuantitatif. Jenis penelitian ini menggunakan rancangan penelitian deskriktif karena penelitian ini bertujuan untuk mengetahui hubungan antar variabel dependen dengan variabel dependen (Dahlan, 2011).

\section{Populasi dan Teknik Sampel}

Populasi adalah wilayah generalisasi yang terdiri atas objek atau subjek yang mempunyai kuantitas dan karakteristik tertentu yang ditetapkan oleh peneliti untuk dipelajari dan kemudian ditarik kesimpulannya (Hidayat AA, 2017). Adapun populasi dalam penelitian ini adalah Ibu yang memiliki Bayi umur 6-24 bulan sebanyak 184 orang di Puskesmas Caile Kabupaten Bulukumba. Tehnik sampling adalah suatu proses dalam menyeleksi sampel yang digunakan dalam penelitian dari populasi yang ada, sehingga jumlah sampel akan mewakili keseluruhan populasi yang ada (Hidayat A.A, 2017). Dalam penelitian ini tehnik sampling yang digunakan peneliti adalalah consecutive sampling yang merupakan semua subjek yang datang dan memenuhi kriteria pemilihan dimasukkan dalam penelitian sampai jumlah subjek yang diperlukan terpenuhi (Hidayat, 2017).

\section{Instrumen Pengumpulan Data}

Instrumen penelitian adalah suatu alat pengumpul data yang digunakan untuk mengukur fenomena dan mencari informasi yang lengkap mengenai masalah yang ingin diketahui dalam suatu penelitian (Sugiyono, 2014). Adapun jenis instrumen yang di gunakan pada penelitian ini adalah lembar kuesioner.

\section{Analisa Data}

Analisa data yang digunakan peneliti untuk menguji hipotesis yang telah ditetapkan yaitu dengan mempelajari pengaruh masing-masing variabel. Untuk mengetahui ada tidaknya pengaruh antara variabel independen dengan variabel dependen maka analisa data yang digunakan penulis adalah analisis bivariat dengan uji chi-square. 


\section{HASIL}

Berdasarkan tabel 1 dapat diketahui dari 65 jumlah responden umur ibu yang terbanyak pada kategori umur 30-39 tahun sebanyak 34 orang (52,3\%), sedangkan yang sedikit dengan kategori umur $\geq 40$ tahun sebanyak 5 orang $(7,7 \%)$. Berdasarkan pendidikan ibu yang terbanyak pada kategori SMP sebanyak 26 orang (40,0\%), sedangkan yang sedikit dengan kategori SMA sebanyak 14 orang (21,5\%). Berdasarkan pekerjaan ibu dari 65 jumlah responden yang terbanyak dengan kategori ibu rumah tangga sebanyak 59 orang $(90,8 \%)$, sedangkan yang sedikit dengan kategori wiraswasta sebanyak 6 orang $(9,2 \%)$. Sedangkan berdasarkan umur anak yang terbanyak pada kategori 1-2 tahun sebanyak 41 orang $(63,1 \%)$, sedangkan yang sedikit dengan kategori 0-1 tahun sebanyak 24 orang $(36,9 \%)$.

\section{Tabel 1. Distribusi Jumlah Responden Berdasarkan Karakteristik Responden}

\begin{tabular}{|c|c|c|}
\hline Karakteristik Responden & Frekuensi (f) & Persentase $(\%)$ \\
\hline \multicolumn{3}{|l|}{ Umur Ibu } \\
\hline 20-29 Tahun & 26 & 40,0 \\
\hline 30-39 Tahun & 34 & 52,3 \\
\hline$\geq 40$ Tahun & 5 & 7,7 \\
\hline \multicolumn{3}{|l|}{ Pendidikan Ibu } \\
\hline SD & 25 & 38,5 \\
\hline SMP & 26 & 40,0 \\
\hline SMA & 14 & 21,5 \\
\hline \multicolumn{3}{|l|}{ Pekerjaan Ibu } \\
\hline IRT & 59 & 90,8 \\
\hline Wiraswasta & 6 & 9,2 \\
\hline \multicolumn{3}{|l|}{ Umur Anak } \\
\hline 0-1 Tahun & 24 & 36,9 \\
\hline 1-2 Tahun & 41 & 63,1 \\
\hline Jumlah & 65 & 100 \\
\hline
\end{tabular}

Berdasarkan tabel 2 dapat diketahui dari 65 jumlah responden pengetahuan ibu tentang pemberian makanan pendamping ASI yang terbanyak pada kategori baik dan cukup sebanyak 44 orang $(67,7 \%)$, sedangkan yang sedikit dengan kategori baik sebanyak 21 orang $(32,3 \%)$. 
Tabel 2. Distribusi Jumlah Responden Berdasarkan Pengetahuan Ibu Tentang Pemberian MP-ASI

\begin{tabular}{ccc}
\hline Pengetahuan Ibu & Frekuensi & Persentase \\
\hline Baik dan Cukup & 44 & 67,7 \\
Kurang & 21 & 32,3 \\
\hline Jumlah & $\mathbf{6 5}$ & $\mathbf{1 0 0}$ \\
\hline
\end{tabular}

Berdasarkan tabel 3 dapat diketahui dari 65 jumlah responden ketepatan pemberian makanan pendamping ASI yang terbanyak pada kategori tepat sebanyak 38 orang $(58,5 \%)$, sedangkan yang sedikit dengan kategori tidak tepat sebanyak 27 orang $(41,5 \%)$.

Tabel 3. Distribusi Jumlah Responden Berdasarkan ketepatan pemberian MP-ASI

\begin{tabular}{|c|c|c|}
\hline Ketepatan Pemberian MP-ASI & Frekuensi & Persentase \\
\hline Tepat & 38 & 58,5 \\
Tidak Tepat & 27 & 41,5 \\
\hline Jumlah & $\mathbf{6 5}$ & $\mathbf{1 0 0}$ \\
\hline
\end{tabular}

Berdasarkan tabel 4 diketahui bahwa responden dengan tingkat pengetahuan ibu tentang makanan pendamping ASI kategori baik dan cukup dengan ketepatan pemberian makanan pendamping ASI kategori tepat sebanyak 32 responden (72,7\%). Sedangkan tingkat pengetahuan ibu tentang makanan pendamping ASI kategori baik dan cukup dengan ketepatan waktu pemberian makanan pendamping ASI kategori tidak tepat sebanyak 12 responden (27,3\%). Serta tingkat pengetahuan ibu tentang makanan pendamping ASI kategori kurang dengan ketepatan pemberian makanan pendamping ASI kategori tepat sebanyak 6 responden $(28,6 \%)$. Dan yang tingkat pengetahuan ibu tentang makanan pendamping ASI kategori kurang dengan ketepatan pemberian makanan pendamping ASI kategori tidak tepat sebanyak 15 responden $(71,4 \%)$.

Hasil analisis dengan menggunakan uji chi-suare diperoleh nilai significancy sebesar 0,001 ( $p<0,05)$, maka dapat disimpulkan bahwa "Terdapat Hubungan antara tingkat pengetahuan ibu tentang makanan pendamping ASI dengan ketepatan pemberian makanan pendamping ASI di wilayah kerja puskesmas caile kabupaten bulukumba". 
Tabel 4. Analisis Hubungan Antara Tingkat Pengetahuan Ibu Tentang Makanan Pendamping ASI Dengan Ketepatan Pemberian Makanan Pendamping

\begin{tabular}{|c|c|c|c|c|c|c|c|}
\hline & & \multicolumn{4}{|c|}{$\begin{array}{c}\text { Ketepatan Pemberian } \\
\text { MP-ASI }\end{array}$} & \multirow[t]{3}{*}{ Total } & \multirow[t]{3}{*}{ P Value } \\
\hline & & \multicolumn{2}{|c|}{ Tepat } & \multicolumn{2}{|c|}{ Tidak tepat } & & \\
\hline & & $\mathbf{n}$ & $\%$ & $\mathbf{n}$ & $\%$ & & \\
\hline \multirow{2}{*}{$\begin{array}{l}\text { Pengetahuan Ibu } \\
\text { tentang MP-ASI }\end{array}$} & Baik & 32 & 72,7 & 12 & 27,3 & 44 & \multirow{3}{*}{0,001} \\
\hline & Kurang & 6 & 28,6 & 15 & 71,4 & 21 & \\
\hline Total & & 38 & 58,5 & 27 & 41,5 & 65 & \\
\hline
\end{tabular}

\section{PEMBAHASAN}

Berdasarkan hasil penelitian dapat diketahui dari 65 jumlah responden pengetahuan ibu tentang pemberian makanan pendamping ASI yang terbanyak pada kategori baik dan cukup sebanyak 44 orang $(67,7 \%)$, sedangkan yang sedikit dengan kategori baik sebanyak 21 orang $(32,3 \%)$.

Berdasarkan penelitian (Andriyani, 2018) tentang hubungan pengetahuan ibu tentang mpasi terhadap waktu pemberian makanan pendamping ASI pada bayi menunjukkan bahwa dari 78 responden ibu memberikan makanan pendamping ASI kepada bayi pada waktu yang tidak tepat yakni sejumlah 45 orang $(57,7 \%)$. Hasil ini sejalan pula dengan penelitian (Rashid and Nuh, 2017) hubungan antara pengetahuan dan sikap ibu dengan perilaku pemberian makanan pendamping asi pada balita usia 6-24 bulan di puskesmas padang bulan, menunjukkan bahwa sebagian besar responden mempunyai perilaku baik dalam pemberian makanan pendamping ASI pada bayi yaitu sebanyak 33 orang (62.3\%). Berdasarkan hasil penelitian dapat diketahui dari 65 jumlah responden ketepatan pemberian makanan pendamping ASI yang terbanyak pada kategori tepat sebanyak 38 orang $(58,5 \%)$, sedangkan yang sedikit dengan kategori tidak tepat sebanyak 27 orang $(41,5 \%)$.

Hasil ini sejalan dengan penelitian (Rohmatika, 2012) hubungan tingkat pengetahuan ibu dengan pemberian makanan pendamping asi bayi umur 6-24 bulan di posyandu karyamulya jetis jaten menunjukkan bahwa pemberian makanan pendamping ASI dengan tingkatan baik sebanyak 26 responden $(86,7)$, tingkatan cukup sebanyak 3 responden $(10,0 \%)$ dan tingkatan kurang sebanyak 1 responden (3,3\%). Hasil yang sama dengan penelitian (Andriyani, 2018) tentang hubungan pengetahuan ibu tentang mp-asi terhadap waktu pemberian makanan 
pendamping ASI pada bayi bahwa pengetahuan ibu tentang makanan pendamping ASI sebagian besar responden berpengetahuan rendah yaitu 42 orang $(53,8 \%)$, dan berpengetahuan tinggi 36 orang (46,2\%). Didukung pula oleh penelitian (Rashid and Nuh, 2017) tentang hubungan antara pengetahuan dan sikap ibu dengan perilaku pemberian makanan pendamping ASI pada balita usia 6-24 bulan di puskesmas Padang Bulan menunjukkan bahwa pengetahuan responden tergolong baik $(52,8 \%)$. Sedangkan berdasarkan penelitian (Tristanti, 2018) pengetahuan ibu tentang makanan pendamping asi bagi bayi umur 6-12 bulan ditinjau dari karakteristik ibu menunjukan bahwa tingkat pengetahuan ibu tentang makanan pendamping ASI sebagian besar responden memiliki pengetahuan yang cukup yaitu sebanyak 13 responden (43,3\%).

Berdasarkan hasil penelitian diketahui bahwa responden yang tingkat pengetahuan ibu tentang makanan pendamping ASI kategori baik dan cukup dengan ketepatan pemberian makanan pendamping ASI kategori tepat sebanyak 32 responden (72,7\%). Serta tingkat pengetahuan ibu tentang makanan pendamping ASI kategori kurang dengan ketepatan pemberian makanan pendamping ASI kategori tepat sebanyak 6 responden (28,6\%). Dan yang tingkat pengetahuan ibu tentang makanan pendamping ASI kategori kurang dengan ketepatan pemberian makanan pendamping ASI kategori tidak tepat sebanyak 15 responden $(71,4 \%)$.

Hasil ini sejalan pula dengan penelitian (Permatasari, 2019) bahwa hasil penelitian dengan uji chisquare diperoleh nilai $\mathrm{p}$ value $0,000<\alpha=0,05$ yang berarti bahwa H1 diterima sehingga terdapat hubungan antara tingkat pengetahuan ibu dengan pemberian makanan pendamping ASI dini. Hasil ini sejalan pula dengan penelitian (Rashid and Nuh, 2017) hasil analisa statistik dengan menggunakan uji chi-square diperoleh nilai p value $=0,040(\mathrm{p}<0,05)$, artinya ada hubungan secara signifikan antara sikap ibu dengan perilaku pemberian makanan pendamping ASI pada bayi

\section{KESIMPULAN DAN SARAN}

Kesimpulan dari penelitian ini adalah bahwa Tingkat pengetahuan ibu tentang pemberian makanan pendamping ASI paling banyak pada kategori baik dan cukup sebanyak 44 orang.Ketepatan waktu pemberian makanan pendamping ASI paling banyak kategori tepat sebanyak 38 orang. Terdapat hubungan antara tingkat pengetahuan ibu tentang makanan pendamping ASI dengan ketepatan waktu pemberian makanan pendamping ASI di wilayah kerja puskesmas Caile Kabupaten Bulukumba. Kami sarankan kepada pihak puskesmas 
setempat untuk selalu memberikan edukasi kepada Ibu bersalin dalam memberikan ASI kepada bayinya.

\section{DAFTAR PUSTAKA}

Ahmad, A., Madanijah, S., Dwiriani, C. M., \& Kolopaking, R. (2019). Pengetahuan, sikap, motivasi ibu, dan praktik pemberian MP-ASI pada anak usia 6-23 bulan: studi formatif di Aceh. Jurnal Gizi Klinik Indonesia, 16(1), 1. https://doi.org/10.22146/ijcn.34560

Andriyani Rika. 2018. Hubungan Pengetahuan Ibu Tentang Mp-Asi Terhadap Waktu Pemberian Mp-Asi Pada Bayi. Jurnal Penelitian Kesehatan Suara Forikes Volume 9 Nomor 1, Januari

Anwar, C., \& Ulfa, Z. (2018). Hubungan Pengetahuan dan Status Pekerjaan Ibu dengan Pemberian MP- ASI pada Bayi Usia 7-12 Bulan di Wilayah Kerja Puskesmas Batoh Banda Aceh Tahun 2018 Relationship between Knowledge and Employment Status of Mothers with Giving Breast Milk in Babies 7-12. Journal of Healthcare Technology and Medicine, $4(1), 29-41$.

Arikunto. (2006). Pedoman riset praktis untuk profesi perawat. https://books.google.co.id/books?id=uVQetJXybEYC

Arini. 2014. Mengeksplorasi Bagaimana Pengalaman Ibu Bekerja Dalam Keberhasilan Pemberian Makanan Pendamping ASI (MP-ASI) Secara Tepat waktu. Badan Pusat Statistik.

Baharuddin, Afriyani. 2016. Faktor-Faktor Yang Berhubungan Dengan Pemberian Mp-Asi Pada Bayi Usia 0-6 Bulan Di Bpm Nurtila Palembang. jurnal poltekkes

Dian. (2015). MPASI Perdana Cihuy: Pedoman Makanan Pendamping ASI usia 6-12 bulan. https://books.google.co.id/books?id=oJaYCwAAQBAJ\&pg=PP17\&dq=frekuensi+maka nan+pendamping+asi+usia+6+bulan\&hl=en\&sa=X\&ved=0ahUKEwiZkJzi5drSAhVFGJ QKHc32A_0Q6AEIRTAH\#v=onepage $\& \mathrm{q}=$ frekuensi makanan pendamping asi usia 6 bulan $\& \mathrm{f}=$ false

Efendi, N. F. (2008). Pendidikan Dalam Keperawatan - Google Buku (p. Bab 2 pages 15).

Heryanto, Eko. 2017. Faktor-Faktor yang Berhubungandengan Pemberian Makanan Pendamping ASI Dini. Jurnal Ilmu Kesehatan : Stikes Aisyah.

Hidayat, A. A. A. (2017) Metodologi Penelitian Keperawatan dan Kesehatan -. Jakarta: Salemba Medika.

Indrawati, I., \& Anggini, P. Q. (2018). Hubungan Pengetahuan Dan Motivasi Ibu Dengan 
Pemberian Mp-Asi Di Wilayah Kerja Puskesmas Rawasari Kota Jambi. Jurnal Akademika Baiturrahim Jambi, 7(1), 70. https://doi.org/10.36565/jab.v7i1.67

Meta. (2019). Mommyclopedia, fakta tentang MPASI.

Nursalam. (2011). Konsep \& Metode Keperawatan (ed. 2) (p. 97).

Permatasari Dian Indah. 2019. Hubungan Tingkat Pengetahuan Ibu Dengan Pemberian Mp-Asi Pada Bayi Usia Kurang 6 Bulan Di Wilayahkerjapuskesmas Gemarang. Stikes Bhakti Husada Mulia Madiun

Rashid Mohd, Nuh Muhammad. 2017. Hubungan Antara Pengetahuan dan Sikap Ibu Dengan Perilaku Pemberian Makanan Pendamping ASI Pada Balita Usia 6-24 Bulan di Puskesmas Padang Bulan. Universitas Sumatera Utara

RI DK (2018) Riset kesehatan dasar (RISKESDAS) 2018. Laporan Provinsi Sulawesi Selatan

Rohmatika Dheny . 2012. Hubungan Tingkat Pengetahuan Ibu Dengan Pemberian Makanan Pendamping Asi Bayi Umur 6-24 Bulan Di Posyandu Karyamulya Jetis Jaten. Stikes Kusuma Husada Surakarta

Safitri Salmah. 2016. Determinan Yang Berhubungan Dengan Pemberian Mp-Asi Pada Bayi Usia 0-6 Bulandi Kelurahan Lalombaa Kecamatan Kolaka Kabupaten Kolaka. Fakultas Kesehatan masyarakat Universitas Diponegoro

Sari, A. C., \& Wigunantiningsih, A. (2010). Hubungan Tingkat Pengetahuan Ibu Menyusui Dengan Ketepatan Waktu Pemberian Makanan Pendamping ASI (MP ASI) di Posyandu Bunga Krisan Tulakan Sine Ngawi. Maternal, 3, 73-83.

Sugiharti, R. K. (2017). Hubungan Antara Paritas dan Umur Ibu dengan Pemberian MP-ASI Dini Pada Bayi Umur < 6 BULA. 2008.

Sugiyono, 2014. Metode penelitian kuantitaif, kualitatif dan R\&D. Alfabeta, Bandung.

Tristanti Ika. 2018. Pengetahuan Ibu Tentang Makanan Pendamping Asi Bagi Bayi Umur 6-12 Bulan Ditinjau Dari Karakteristik Ibu. Jurnal Ilmu Keperawatan dan Kebidanan Vol.9 No.1 66-74

Wahyudi, setyo tri. (2017). Statistika Ekonomi Konsep, Teori dan Penerapan - Setyo Tri Wahyudi - Google Buku (p. 221 hlm). https://books.google.co.id

Yuliarti, Nurheti. 2014. Keajaiban ASI Makanan Terbaik untuk Kesehatan, Kecerdasan, dan Kelincahan si Kecil. Yogyakarta:Penerbit Andi 